\title{
CPEC: A WIN-WIN FOR CHINA AND PAKISTAN
}

\author{
KIRAN HASSAN
}

\begin{abstract}
The China-Pakistan Economic Corridor (CPEC) is believed to be Beijing's most ambitious project so far. Two types of apprehensions are often voiced to support this claim. First, it is widely argued that despite enjoying enduring strategic partnership for over five decades, Pakistan and China don't match economically. The Chinese will get weary of the many challenges coming with the corrupt, inefficient and globally isolated Pakistan, seriously undermining the conclusion of the Chinese mammoth investment in CPEC Secondly, Pakistan's prevailing environment of insecurity which is rife with Islamic militancy and domestic insurgency is thought to be posing serious threats to the construction of the corridor. This paper aims to explain why, despite possible concerns, the China Pakistan economic corridor will succeed.
\end{abstract}

Keywords: China; Pakistan; Economic Corridor; global power

\section{Introduction}

The China-Pakistan Economic Corridor (CPEC) is believed to be Beijing's most ambitious project so far. Two types of apprehensions are often voiced to support this claim. First, it is widely argued that despite enjoying an enduring strategic partnership for over five decades, Pakistan and China do not match economically. The Chinese will get weary of the many challenges coming out of corrupt, inefficient and globally isolated Pakistan, and that will seriously undermine the outcome of China's mammoth investment in the CPEC (Calabrese, 2015). Secondly, Pakistan's prevailing environment of insecurity, which is rife with Islamic militancy and domestic insurgency, is thought to be posing serious threats to the construction of the corridor (Sial, 2016). Despite the partial plausibility of these observations, this paper aims to explain why, despite possible concerns, the China Pakistan economic corridor will succeed. The culmination of the CPEC will be of huge financial benefit to China and Pakistan, reshaping the Pakistani economy; the corridor will offer global connectivity to militancy ridden western Pakistan, containing Islamic extremism and thereby improving regional relationships. Finally, CPEC's success will be the proof of China's win-win foreign policy and its positive conclusion will prove China's serious commitment to other BRI countries, propelling it into the position of a serious and critical global power. 


\section{The inclusive economic and energy corridor}

The CPEC's official website presents the China Pakistan Economic Corridor as a journey towards economic regionalization in the globalized world. Offering inclusivity, the CPEC envisages regional connectivity, which will not only benefit China and Pakistan but will have a positive impact on Iran, Afghanistan, India, the Central Asian republics, and the region. The aim of the trade route is to enhance geographical linkages which will focus on an improved transportation system, promoting people to people contact through academic, cultural and knowledge activity. Greater importance will be given to the volume of trade and energy flows. It is a win-win model which will result in a well-connected, integrated region of shared destiny, harmony, and development (Official website of the CPEC).

According to an official agreement signed between China and Pakistan in 2017, the longterm plan for the implementation of this corridor is envisaged to span 2017 to 2030. Both governments agreed to finish CPEC short-term projects by 2020, mid-term projects by 2025 , and final projects by 2030.They mutually agreed to divide the CPEC into five functional zones: 1) Xinjiang foreign economic zone, 2) Northern border trade logistics and business corridor \& ecological reserve, 3) Eastern and central plain economic zone, 4) Western logistics corridor business zone, and 5) Southern coastal logistics business zone. The transportation corridors and industrial clusters will be concentrated in these zones (LongTerm Plan for China-Pakistan Economic Corridor).

According to The Gilgit Times, the corridor is a 3,218-kilometre-long route consisting of highways, railways, pipelines, and sea ports. This trade route passes through Pakistan's Gilgit-Baltistan province and connects China's western province of Xinjiang Kashgar to the rest of the world. The Chinese-operated Gwadar port in the south of Pakistan holds special significance for the CPEC. The actual estimated cost of the project is expected to be US\$75 billion, with US $\$ 45$ billion of that going on ensuring the corridor becomes operational by 2020 . The remaining investment will be spent on energy generation and infrastructure development.

The Chinese officially pledged to support the CPEC in April 2015. The formalization of this long-term economic commitment was perceived and presented as furthering the SinoPak longstanding strategic relationship (Calabrese, 2015). Both countries had often referred to each other as "all-weather friends" and "Iron Brothers" because of past collaborations in issues around trade, investment, culture, education, science, technology, security and defence. Each has stood by the other on various International fronts. Pakistan fully backed China with regards to Taiwan, Xinjiang, Xizang [Tibet], and the South China Sea. Similarly, China is firmly behind Pakistan's independence, sovereignty, and national dignity (Weidong, 2017).

Many western powers perceive the CPEC as a symbol of an aggressive China because through this pathway China has access to the two most critical trade routes in the BRI. The trade was and is pivotal to making way for China to access continental Eurasia through the "Silk Road Economic Belt" and Africa and the Middle East through Gwadar as part of the "Maritime Silk Road". Although Beijing is quick to downplay geostrategic motivations behind the CPEC, many commentators have noted that, over the long run, an overland link 
across Pakistan to the Arabian Sea could help alleviate China's "Malacca dilemma," for China remains vulnerable in South East Asia as approximately 85 percent of its current oil imports travel through the single chokepoint of the Strait of Malacca (Markey \& West, 2016).

\section{CPEC: China's pivot to global power}

The CPEC brings two obvious interlinked gains for China. It is planned to speed up China's energy/trade routes with the wider world, which will in turn greatly accelerate the Chinese economy and its international status. The Chinese are also comfortable in bringing their biggest BRI investment (64 billion dollars) into the CPEC because of the time-tested solid relationship that they already share with the Pakistanis.

President Xi's initial grand strategic concept, called "One Belt One Road" (OBOR) which was later renamed the BRI (Belt and Road Initiative) was to connect China with over 60 countries and regions. This strategy of entailing developing infrastructure along with creating a large economic market through strengthening partnerships between China and this large group of Central Asian, European, Middle Eastern, North African and Southeast Asian countries holds a special appeal for the Chinese. It will provide a massive upsurge in Chinese exports, thereby promoting China's economic growth. China has been actively involved with regional trade organizations worldwide since the end of the last century but with BRI China is consolidating its economic ties with these countries (Chen et al., 2018).The emergence of China as the world's largest creditor is also an important development in the world economy today. In addition to direct investment, China is involved in significant overseas lending, primarily through the Export-Import Bank of China (China EXIM Bank) and the China Development Bank (CDB). In recent years, each bank has been lending about $\$ 100$ billion overseas and many of these overseas investments by China take place under the rubric of the BRI initiative. China's recipient countries welcome these direct investments because the Chinese money lending comes along with BRI's vision for expanded infrastructure along the traditional Silk Road route (Dollar, 2016).

The CPEC, especially the port of Gwadar is becoming crucial for China's speedy access to these markets. Both China and Pakistan decided to develop the port of Gwadar in 2015, when President Xi Jinping visited Islamabad. The aim is to link Gwadar to landlocked western China, including its Muslim-majority Xinjiang region, giving it access to a shorter and secure route through Pakistan to global trade. The port will also provide the shortest route to landlocked Central Asian countries, including Afghanistan, through transit trade and offering transhipment facilities.As 60 percent of China's energy requirements come from the Persian Gulf, Gwadar Port will help China make use of this as the most appropriate and direct approach to the markets of the Gulf Region and Africa. The maritime trade route to the Middle East passes through South China and is expensive and heavily patrolled by the United States. The Gwadar trade route will reduce the distance for Chinese vessels from 10,000 km to just 2,500 km. Gwadar Port is also China's alternative route if access through Malacca strait is denied (Malik, 2012).

But the borrowed Chinese money is also seen as a debt trap for many struggling economies. For instance, the Chinese invested in the sea port of Hambantota in Sri Lanka. With tens of thousands of ships passing through one of the world's busiest shipping lanes, 
the port drew in only 34 ships in 2012 and did not reap the envisaged results. Therefore, Sri Lanka's new government struggled to make payments on the Chinese debt. Under heavy pressure and after months of negotiations with the Chinese, the government handed over the port and 15,000 acres of land around it for 99 years in December 2015. The debt deal also intensified some of the harshest accusations about President Xi Jinping's signature Belt and Road Initiative: that the global investment and lending programme amounts to a debt trap for vulnerable countries around the world, fuelling corruption and autocratic behaviour in struggling democracies (Habib, 2018)

Similar concerns are expressed regarding the Chinese investment in CPEC. China has started other projects such as the Bangladesh, China, India, and Myanmar (BCIM) Corridor; Silk Route in Central Asia; and the 21st Century Maritime Silk Route. The CPEC is often referred to as China's "flagship" project. China's enduring friendship with Pakistan is one amongst the many reasons why the Chinese feel secure and prioritize the CPEC over many other BRI projects. The argument is that the Sino-Pak relationship has stood the test of time and the challenges, and so it will this time too (Ali, 2016).

\section{CPEC: A wish list for Pakistan's economy}

The CPEC is usually referred to as a game changer for Pakistan's economy and geopolitical positioning. Pakistan is expected to reap huge benefits in the fields of energy, agriculture, developmental infrastructure, and local employment if this economic corridor succeeds. Pakistan's regional and global position is also likely to see a strong boost with the positive conclusion of the CPEC. The geopolitics of South Asia are likely to transform as a result of the strengthening of the existing solid Sino-Pak relationship, triggering concerns for India. Gwadar Port under the control of China turning into a permanent Chinese naval facility also gives Pakistan's less friendly neighbours the jitters.

Over 140 million Pakistanis either have no access to the power grid or suffer over 12 hours of load shedding daily. The average shortfall in the power sector is 4,000 MW. Pakistan has suffered from chronic power shortages in the form of load-shedding and power outages in recent years, causing the loss of billions of rupees, severely shrinking the local industry, causing wide-scale unemployment and seriously undermining the Pakistani economy.

The Chinese are committed to improving the energy situation in Pakistan. As world leaders in wind and solar installed renewable energy, they have promised $\$ 35 \mathrm{~B}$ for multiple power generation and transmission projects. The investment is spread over 17 power generation projects and one HVDC transmission project under the CPEC energy agreements. Chinese companies, under the CPEC, will be working on four wind power projects of 300 MW capacity, one solar power project of $900 \mathrm{MW}$, three hydro power projects of 2,714 MW, five coal projects in Thar Sindh of 3,960 MW, and four imported coal projects of 4,260 MW in total, along with a $\pm 660 \mathrm{kV}$ HVDC transmission line between Sindh and Punjab (Zahid, 2018).

The CPEC energy projects in Pakistan have been part of Pakistan's CPEC wish list compiled by the Chinese. Prioritizing overcoming energy shortage, the Chinese helped Pakistan in installing the Chashma 1 and Chashma 2 power plants, which are already 
producing electricity. In 2017 China has signed another deal to install the Chashma 3 and Chashma 4 power plants. Each power plant will produce 1,000 megawatts of electricity after completion. They are also building two HUOLONG ONE nuclear reactors in Karachi that will become ready to use by 2021 (Christopher, 2018).

Through the CPEC Pakistan is also addressing its looming unemployment. The News, (January 2019) reports that the latest figures show that CPEC projects will provided jobs to 70,000 Pakistanis by 2030 and are expected to generate 0.7 million more employment opportunities in the future. The CPEC is projected to generate 2,320,000 jobs, ultimately reducing Pakistan's unemployment rate from 5.5 percent to 3.9 percent (Chen et al., 2018). But according to former Chinese ambassador to Pakistan Lu Shuling, the CPEC promises economic benefits, including large scale employment, which will contain Pakistan's domestic terrorism problem. According to him: "The best medicine to address the terrorism problem is through tackling the incubator of terrorism, namely poverty" (Cai, 2017).

The CPEC also enjoys immense popularity amongst Pakistanis. In a recent Pew survey, 78 percent of Pakistanis viewed China favourably, compared to the 14 per cent of Pakistanis who looked positively upon the United States. Pakistan's capacity to sustain the mammoth infrastructure created by the CPEC is an ideal platform for the unemployed, unskilled youth bulge in Pakistan to learn and master Chinese craftsmanship.

While China is helping Pakistan train a highly skilled Pakistani labour work force as part of the CPEC's strategy, the Chinese are also directing Pakistan towards technological advancement. According to Defence PK (November 2018), in 2018, Alibaba bought Pakistan's largest e-commerce platform, Daraz.pk. While Ant Financial Services, China's biggest online payment service provider, recently bought a 45 percent stake in Telenor Microfinance Bank, in a deal that valued the Pakistani bank at \$410 million. Irfan Wahab, chief executive of Telenor Pakistan, called this deal a "game changer"; while Eric Jing, chief executive of Ant Financial, said it would provide "inclusive financial services in a transparent, safe, low-cost and efficient way to a largely unbanked and underbanked population in Pakistan". This kind of investment will benefit from the significant demographic dividend in Pakistan, targeting the largely unbanked young population, and providing not only financial inclusion but also a base on which to build digital businesses. At the World Economic Forum in 2017, eBay's chief executive, Devin Wenig, highlighted Pakistan as one of the fastest growing e-commerce markets in the world. Emerging from many years of the war on terror, the terror-stricken country is now on a decent path to progress, with an annual economic growth of 5.8 percent. The technological and developmental injections into the Pakistani economy will improve investor confidence in a post 9/11 globally isolated Pakistan.

\section{Gwadar: Sino-Pak dream shipping hub}

Gwadar port is the jewel of the CPEC projects. It is a Pakistani sea port which the Pakistanis have given to the Chinese on lease. The lessee, state-owned China Overseas Port Holding Company, has been building out the port's infrastructure since 2013. Gwadar enjoys much significance in the CPEC because it is a deep sea port in a geographically strategic location. Located in southern Pakistan's Baluchistan province on the Makran coast of the Arabian, 100 
$\mathrm{km}$ from the border with Iran and $400 \mathrm{~km}$ from the Straits of Hormuz, it is envisaged as an energy transport corridor (Calabrese, 2015).

Historically, Gwadar was once a small backward fishing town off the Arabian Sea. It was owned by the Kingdom of Oman for 200 years. The port was sold to Islamabad on 8th December 1958 for $\$ 3$ million. Plans to develop Gwadar were first introduced in 1992 but due to the lack of resources on one hand and international sanctions against Islamabad for pursuing atomic bomb on the other, the port could not become operational. The Chinese agreed to invest in this project with the first phase of the development plan starting in 2002. In 2007 the construction of the first phase was completed and on 15th March 2008 Gwadar Port was launched with the arrival of 70,000 tonnes of cargo (Pourtajrish, 2018).

The Nation (April, 2017) reports that in late 2015 the port was leased to China for 43 years, until 2059. China Overseas Port Holding Company (COPHC) has 91 per cent share of revenue collection from gross revenue of terminal and marine operations and 85 per cent share from gross revenue of free zone operation. The port is expected to start operating in three to four years. According to a Chinese newspaper, the deep-water port became fully functional in late 2016 under the China-Pakistan Economic Corridor and welcomed its first liner in March 2018. Some 20 companies in different businesses have already joined the Gwadar free trade zone with direct investment of around $\$ 460$ million (Jabri, 2018). Officials expect Gwadar's cargo handling capacity to increase exponentially, making it South Asia's biggest shipping centre within five years, with a yearly handling capacity of 13-million tonnes of cargo. And by 2030, they say, it will be capable of handling up to 400-million tonnes of cargo annually (Gul, 2017). Gwadar port will seal the CPEC marriage between China and Pakistan. Both countries have much to gain economically and geo-strategically out of the success of Gwadar.

\section{CPEC: Rooting out Islamic militancy or solving the Afghanistan conundrum?}

The rise of Islamic militancy in Afghanistan and Pakistan is predicted to challenge the success of the CPEC and its projects. Pant (2012) argues that China's concerns about Islamist militancy on its western border have been increasing over the past few years and the security environment in Afghanistan and the larger central Asian region remains a huge Chinese worry (Pant, 2012). Indeed, with the rise of the Taliban in Afghanistan, China was seen as fearing the Islamic threat with regards to its Uighur population. The Chinese concerns were further compounded with the Islamic movement of Uzbekistan (IMU), when a jihadi group with ties to Al-Qaeda, began to recruit Uighurs from the vast network of Pakistani madrassas, many of which follow the conservative Deobandi teachings and advocate jihad (Haider, 2005).

The Chinese concern about Uighur unrest is not new. During the 1990s China even covertly attempted to reach out to the Taliban and urge them to stop supporting the Uighur insurgency in China. At the time the Pakistanis, although remaining sympathetic, never openly favoured the Chinese Uighurs. Through the 1990s, as the Chinese government cracked down on the region, Pakistan showed that although it tolerated the Uighurs' presence on its soil, no support would be provided for their cause. During the early 2000s, Islamabad placed pressure on religious leaders running madrassas not to accept any Uighurs. 
Although this caused some tensions between the mullahs and the government, the Pakistani government retained its position. For example, in a visit to China's Shaanxi province in 2001, former Pakistan president Pervez Musharraf met with the imam of the grand mosque in Xi' an and urged all Chinese Muslims to be patriotic, shun violence and work for the good of China (Haider, 535, 536).

With the CPEC's projects underway, there are two trends worth noting. Islamic militancy has been on the decline in Pakistan, and China is playing a more active role in improving regional economies. The Chinese promise of trade routes, energy hubs, jobs, and connectivity are incredibly attractive to the isolated heartlands of Islamic militancy, therefore the message around anti-Americanism and jihad against the west is likely to take a serious back foot.

Additionally, China's engagement with Afghanistan is also transforming. Since 2014, however, Chinese officials have played an increasingly important role in Afghanistan. Beijing has expressed willingness to step up communications with Kabul. It is no coincidence that the Chinese leadership appointed Sun Yuxi, a senior diplomat familiar with the country as Special Envoy to Afghanistan. China creates very few Special Envoy positions and so this appointment is worth noting. China's recent proactive role in Afghanistan is believed to be self-serving. With NATO withdrawal and the deterioration in the security situation in northern Afghanistan, Beijing is motivated to play mediator. It has reassured Washington that Pakistan will not spoil the peace process and that it seeks to favour a complete US withdrawal from its backyard. China agreed to mediate because it perfectly suits its framework of action, projects a positive image abroad, and adds another feather to its foreign policy cap (Chéné, 2015).

China is interested in the normalization of ties between Afghanistan and Pakistan for the success of the CPEC. For instance, on 15th December 2018, China, Pakistan, and Afghanistan signed a trilateral understanding on enhancing counterterrorism security cooperation, and collectively reiterated their call for the Taliban insurgency to join Afghan peace talks. The Chinese and Pakistani foreign ministers are encouraging the Afghan government to join the China-Pakistan Economic Corridor. China is also promising to help build roads and railways to connect the CPEC with Afghanistan (Gul, 2018).

Pakistan's initiative to fight domestic terrorism is being well received by China. Two military operations named Zarb-e Azb and Rad-ul Fasad have been conducted to target Islamic militancy. The results have led to an improvement in Pakistan's inland security. According to the Global Terrorism Index of 2017, terrorism has been in sharp decline in Pakistan since 2014.

For CPEC projects the Chinese are promised security by the Pakistanis. For example, Pakistan has also deployed an elite Special Security Group; the 10,000-man division will have responsibility for ensuring the safety of the Chinese projects, especially in Baluchistan (Riedel, 2015).With Pakistani Islamic militancy receding and Beijing's new engagement with Afghanistan, the CPEC'S biggest challenge seems to be under control. On most occasions China continues to publicly emphasize that its relationship with Pakistan is far more important than the isolated incidents of violence (Pant, 2012). 


\section{CPEC's completion: Crucial to the BRI's success}

Since the CPEC provides China with a more efficient route into the larger BRI family, it will reward the 69 countries and organizations who have officially signed up to China's "Belt and Road" trade and investment initiative. These partners will be the secondary beneficiaries of this trade route. President Xi Jinping has repeated that the BRI should be jointly built through consultation to meet the interests of all, and efforts should be made to integrate the development strategies of the countries along the route. It is not closed but should be open and inclusive; it is not a solo effort by China but a chorus of all countries along the route. What is noteworthy is that it is gaining momentum and many countries like Iran, Myanmar, Thailand, and Russia, despite their initial apprehensions, have welcomed and embraced the project. While China's primary goal is to ensure its energy and oil supply is met by this initiative, the BRI states from the Mediterranean Sea to the Middle East, Central Asia, South Asia, and South East Asia will take advantage of this (Shafqat, 2017).

For India, the CPEC is especially provocative, as one of its highways crosses through Gilgit-Baltistan, a Pakistan-administered territory that India claims as part of Kashmir, meaning that New Delhi views Beijing's backing for the corridor as tantamount to recognition of Pakistani sovereignty over Gilgit-Baltistan (Stratfor, 2019). Even though, the increasing Chinese footprint in the region makes India uncomfortable, the Chinese approach also remains non-confrontational. Given that in 2012 China did over five times more trade with India than with Pakistan, China may never choose a relationship with India over one with Pakistan, but it would prefer not to make that choice at all. Regionally, China would naturally prefer to have the best of both worlds. It is possible that Pakistan's territory will be useful to China in new ways where, in the coming years, through the CPEC, Pakistani ports and highways could turn into essential lines of communication for a new Chinese land empire. Beijing intends to maintain its "all weather" friendship with Pakistan as it has designs on a long-term future in which Pakistan features, but it also has plans for a stronger trade relationship with India (Markey, 2013). China's newfound proactive foreign policy, especially the BRI, also faces western scepticism. Many Americans especially fear that the Belt and Road Initiative is an extension of efforts by the Chinese Communist Party (CCP) to undermine the security and economic architecture of the international order. China's growing largesse, they worry, comes largely at the expense of international institutions and American influence. By contrast, others consider this Chinese initiative a strategic blunder. They argue that by buying into the flawed idea that barrels of money are all that is needed to solve complex geopolitical problems, China has committed a colossal error and Xi's dictatorship makes it almost impossible for the country to admit this mistake or abandon his pet project (Greer, 2018).

The Chinese BRI plan for global inclusivity is well-presented in a win-win package. They have created a master narrative that copes with transformation, reform, and transition, while maintaining the commitment to a coherent, over arching appealing mission. The mission is especially attractive because it is vague, aspirational and open-ended. Since XI Jinxing became leader, China's foreign policy moved from risk aversive to optimistic dreaming about a better world where China will have recovered its rightful place. Where 
20 years ago China used to keep saying "no", or at best "maybe" to the international community, now it wants to say "yes" to most countries (Ferdinand, 2016).

The Chinese global engagement may be new to the world, but it is familiar to most Pakistanis. Even though it is argued that Pakistan's political inconsistency, lack of policy uniformity, and economic instability make China uncomfortable (Saqib et al., 2015), the Chinese are committed towards bringing advantages to Pakistani finance, technology, and local infrastructure (Weidong, 2017). This is best explained by Professor Li

I visited Sahiwal last week. The young engineers are Pakistanis. The working language for CPEC projects remains English. These engineers are recruited from two universities in Punjab University and Engineering University in Punjab. The Chinese companies are very interested in training the Pakistanis and they are proceeding with capacity building of Pakistani work force. The Chinese are interested in improving Pakistani infrastructure with Pakistani capability. (Professor Li, Lahore, 2018)

But fully investing in the CPEC is even more important to Pakistan than partnering with China which is an emerging global power ensuring Pakistan's own future as a regional and international player both economically and geo-strategically. For decades Beijing's secretive ties with Islamabad have run closer than most formal alliances. Founded on a shared enmity with India, China's backing of Pakistan has gone so deep that it is willing to offer the ultimate gift from one state to another: the materials that Pakistan's nuclear scientists need to build a bomb. Pakistan acted as China's backdoor during its years of domestic isolation, the bridge between Nixon and Mao, and the frontline in Beijing's struggles with the Soviet Union during the last stages of the Cold War. Now, Pakistan is a central part of China's transition from regional power to a global one. The country lies at the heart of Beijing's plans for a network of ports, pipelines, roads, and railways connecting the oil and gas fields of the Middle East to the mega cities of East Asia (Small, 2015). Alienating the West is the last of Pakistan's concerns so the CPEC is fully supported by both the political and military elite of Pakistan. A quote reinforces this

We made the nuclear bomb despite international criticism... we will succeed in making CPEC despite international criticism... nobody could stop us then... nobody can stop us now. (ExPakistani military officer, Lahore, December 2018)

\section{Conclusion}

Martin Jacques in his book, When China Rules the World, predicts a global shift in the twenty-first century in which, amid the rise of non-Western countries, the West will no longer be dominant. He stresses that in this new era of contested modernity the central player will be China. As reported by China Power, China's BRI plan which is extending to 65 countries, combining gross domestic product of $\$ 23$ trillion and including some 4.4 billion people indicates the global fulcrum shifting from the west towards China.

The timing of this Chinese Marshall plan is impeccable because many of the partnering BRI countries have serious needs and their usual western patron, the United States, is neither interested nor committed, under the Trump administration, to ensuring longstanding relief. 
In the recent global shift in which America is failing and China is stepping up, the Asian Development Bank is predicting that the Chinese courted emerging Asian economies need $\$ 1.7$ trillion per year in infrastructure to maintain growth, tackle poverty, and respond to climate change.

The relationship between Pakistan and China is key to China's transition from regional to global power (Small, 2015) because of its geopolitical significance. US and Chinese interests contradict, especially over the CPEC. Moreover, the Sino-Pak long-term shared trade routes, especially in the Indian Ocean, are not favoured by either the United States or India. The declining American influence on Pakistan is particularly concerning as it impacts the American capacity to police the region, including Iran and Russia.

At the same time the Chinese are demonstrating that they are altering the status quo of South Asia. Not only have they helped in the strategic engagement between Pakistan and Russia (Kaushiki \& Ramzan, 2015), they are also pushing for trade doors to open between India, Pakistan, and Afghanistan. The region, especially India, could benefit from the open trade pathways (Butt, 2015). If the Chinese are successful in achieving a mini breakthrough between the age-old estrangement between the south Asian neighbours, it will speedily propel its own status as a global influence. Therefore, regardless of the economic growth, the success of the CPEC is crucial for the Chinese.

American policy seems to be less effective in Pakistan. After many decades of inconsistent engagement, the Pak-US relationship remains problematic. It recently nosedived when Washington failed to leverage a favourable outcome from the Pakistanis in the case of Afghanistan. The simultaneously increasing presence of the Chinese in the region is making some American policy makers critical of America's current stance because the post 9/11 USPakistan partnership has been rife with mutual tensions, unmet demands, and animosities. This observation is best explained in Pakistan Today (January 2018) who quoted Richard G. Olson, the former United States ambassador to Pakistan saying

Mr. Xi's plan stands in stark contrast to President Trump and his "America First" mantra. The harsh truth is that American leverage over Rawalpindi and Islamabad has been declining. And as United States aid levels have diminished China has invested around \$62 billion in Pakistani infrastructure. Its magnitude and its transformation of parts of Pakistan dwarf anything the United States has ever undertaken.

Numerous policy papers have pointed out that, for long-term investor engagement, China needs the quick and successful completion of a few keystone projects in the BRI. This makes the success of the first wave of projects all the more crucial (China Power). The ChinaPakistan Economic corridor remains at the top of that Chinese to-do list.

\section{References}

Ali, A. (2016). China Pakistan Economic Corridor: Prospects and Challenges for Regional Integration. Arts Social Sciences Journal, 7, 204. doi:10.4172/2151-6200.1000204

Butt, K. M. (2015). Impact of CPEC on regional and extra regional actors. Journal of Political Science, XXXIII, (1), 23-44. 
Cai, P. (2017). Understanding China's Belt and Road Initiative. Lowy Institute. Retrieved from https://thinkasia.org/bitstream/handle/11540/6810/Understanding_Chinas_Belt_and_Roa_ InitiativeWEB_1.pdf? sequence $=1$

Calabrese, J. (2015). Balancing on 'the Fulcrum of Asia': China's Pakistan Strategy. Indian Journal of Asian Affairs, 27/28(1/2), 1-20.

Chen, X., Joseph, S.K., \& Tariq, H. (2018). Betting Big on CPEC. Retrieved from https:// digitalrepository.trincoll.edu/cgi/viewcontent.cgi?article=1206\&context=facpub

Chéné, H. (2015). China in Afghanistan - Balancing power projection and minimal intervention. Institute of Peace and Conflict Studies. China Pakistan official website http://cpec.gov.pk/ introduction/1

Christopher, V. (2018, July 16). CPEC and Pakistan-China Energy cooperation. Modern Diplomacy. Retrieved from https://moderndiplomacy.eu/2018/07/16/cpec-and-pakistan-china-energycooperation/

CPEC to create 700,000 direct jobs for Pakistanis by 2030. (2019, January 8). The News. Retrieved from https://www.thenews.com.pk/latest/416259-cpec-to-create-700000-direct-jobs-by-2030

Markey D.S \& West, J. (2016, May 12). Behind China's Gambit in Pakistan (CFR Expert Brief). Retrieved from https://www.cfr.org/expert-brief/behind-chinas-gambit-pakistan

Dollar, D. (2016). China as a global investor. Asia working group, paper 4. Brookings. Retrieved from https://www.brookings.edu/wp-content/uploads/2016/07/China-as-a-Global-Investor_AsiaWorking-Paper-4-2.pdf

Ferdinand, P. (2016). Westward ho- the China dream and 'one belt , one road': Chinese foreign policy under Xi Jinping, International Affairs, 92(4), 941-957.

Greer, T. (2018, December 6). One belt, one road, one big mistake. Foreign Policy. Retrieved from https://foreignpolicy.com/2018/12/06/bri-china-belt-road-initiative-blunder/

Gul, A. (2017, October 24). China Turning Pakistan Port into regional giant. VOA. Retrieved fromhttps://www.voanews.com/a/pakistan-china-gwadar-port/4084175.html,

Gul, A. (2018, December 15). Afghanistan, China and Pakistan Ink Deal to enhance counterterror cooperation. VOA Retrieved from https://www.voanews.com/a/afghanistan-china-and-pakistan-inkdeal-to-enhance-counterterror-cooperation-/4702178.html

Gwadar port leased to Chinese company for 40 years, Senate told. (2017, April 20). The Nation. Retrieved from https://nation.com.pk/20-Apr-2017/gwadar-port-leased-to-chinese-company-for-40years-senate-told

Habib, A. (2018, June 25). How China got Sri Lanka to cough up a Port. The New York Times. Retrieved from https://www.nytimes.com/2018/06/25/world/asia/china-sri-lanka-port.html

Haider, Z. (2005). Sino-Pakistan relations and Xinjiang's uighurs, Asian Survey, 45 (4), 522-545.

How will CPEC boost Pakistan economy? Gilgit Times, (n.d.). Retrieved from https://www2.deloitte. $\mathrm{com} /$ content/dam/Deloitte/pk/Documents/risk/pak-china-eco-corridor-deloittepk-noexp.pdf

How will the Belt and Road Initiative advance China's interests? China Power, (n.d). Retrieved from: https://chinapower.csis.org/china-belt-and-road-initiative/

Jabri, P. (2018 November 12). Gwadar port attracts more businessmen by offering numerous opportunities. Business Recorder. Retrieved from https://www.brecorder.com/2018/11/12/452085/ gwadar-port-attracts-more-businessmen-by-offering-numerous-opportunities/

Kaushiki, N. \& Ramzan, H. (2015). Sino-Russo Strategic Synergy in International Contours of South Asian Equilibrium. Journal of International and Area Studies, 22 (2), 1-18.

Long Term Plan for China-Pakistan Economic Corridor (2017-2030). Retrieved from: https://www. pc.gov.pk/uploads/cpec/LTP.pdf

Malik, H. Y. (2012). Strategic Importance of Gwadar Port Journal of Political Studies. 19(2), 57- 69. Retrieved from: https://www.researchgate.net/publication/277396451_Strategic_Importance_of_ Gwadar_Pot 
Markey, D. S. (2013). No Exit from Pakistan, America's Tortured Relationship with Islamabad. Cambridge: Cambridge University Press.

Olson, R. (2018, January 9). Humiliating Pakistan unlikely to work. Pakistan Today. Retrieved from https://www.pakistantoday.com.pk/2018/01/09/humiliating-pakistan-unlikely-to-work-richardolson/

Pakistan's digital revolution is happening faster than you think. (2018, November 22). Defence P.K. https://defence.pk/pdf/threads/pakistans-digital-revolution-is-happening-faster-than-youthink.588352/

Pant, V. H. (2011). The Pakistan thorn in China-India-U. S. relations. The Washington Quarterly, 35(1), 83-95.

Pourtajrish, V. (2018, April 25). Pakistani Gwadar Port: A double-edged sword for Iran. Modern Diplomacy Retrieved fromhttps://moderndiplomacy.eu/2018/04/25/pakistani-gwadar-port-a-doubleedged-sword-for-iran/

Riedel, B. (2015). The China-Pakistan axis and Lashkar-e-Taiba. Brookings. https://www.brookings. edu/opinions/the-china-pakistan-axis-and-lashkar-e-taiba/

Saqib et al. (2015). One belt and one road: Does China -Pakistan economic corridor benefit for Pakistan's economy? Journal of Economics and Sustainable Development, 6 (24).

Shafqat, S. (2017). China's rise: How it is impacting the Gulf, Iran, Pakistan and beyond? Asian Journal of Middle Eastern and Islamic studies, 11(1).

Sial, S., (2016). The China-Pakistan Economic Corridor: An assessment of potential threats and constraints. Retrieved from http://pakistanhouse.net/wp-content/uploads/2016/11/cpec.pdf

Small, A. (2015). The China-Pakistan Axis: Asia's New Geopolitics. Hurst \& Co Publishers, UK and Oxford University Press USA.

Weidong, S. (2017). Pakistan-China relations: CPEC and beyond. Policy Perspectives. Pluto Journals, $14(2), 3-12$.

World Economic Forum (22 Nov 2018). Pakistan's digital revolution is happening faster than you thinkhttps://www.weforum.org/agenda/2018/11/pakistan-s-digital-revolution-is-happening-fasterthan-you-think/

Why the Belt and Road Fuels India's Fears of encirclement (2019, April 19). Stratfor. W. Retrieved from: https://worldview.stratfor.com/article/chinas-belt-and-road-fuels-indias-fears-encirclementcpec-saarc-bri

Zahid, J. (2018, August 31). How CPEC can help Pakistan's chronic power shortage. China Daily. Retrieved from http://www.chinadaily.com.cn/a/201808/31/WS5b88e0d5a310add14f388e63.html

School of Advanced Study

University of London

Flat 8, Alba Court,

Alba Gardens, Golders Green

NW119NP London

United Kingdom

Email: mnarik@hotmail.com 